\title{
Brazilian sparkling wine: A successful trajectory
}

\author{
Douglas André Wurza, Ricardo Allebrandt, Betina Pereira de Bem, Juliana Reinehr, Adrielen Tamiris Canossa, \\ Luiz Gabriel Dalmolin, Leo Rufato, and Aike Anneliese Kretzschmar
}

Santa Catarina State University (UDESC), College of Agriculture and Life Science, Av. Luiz de Camões, 2090, CEP 88520-000, Lages, SC, Brazil

\begin{abstract}
The objective of this study was to explore the evolution of internal and external commercialization of Brazilian sparkling wines during the period between 1986 and 2015, giving an overview of the current situation and its market trends, and highlighting the importance of Brazil in the world scenario for sparkling wines. This research is based on quantitative data sources provided by different institutions: International Organization of Vine and Wine (OIV), Brazilian Union of Viticulture (UVIBRA), Ministry of Agriculture, Livestock and Supply (MAPA) and Brazilian Agricultural Research Corporation (EMBRAPA). Brazil is a promising country for the sparkling wine market. From 1986-2015, there was an increase of $465.6 \%$ in the sales of sparkling wine in the Brazilian domestic market, especially the last ten, which accounted for an increase of $215.7 \%$. In 1998, Brazilian sparkling wines accounted for $70.5 \%$ of sparkling wines sold in Brazil. Today, they represent $82.1 \%$ of national market, and proved to be one of the most prestigious products from Brazilian viticulture when compared, for example, to non-sparkling wines, which $79 \%$ are imported wines. Of the imported sparkling wines consumed in Brazil, six countries account for $98.5 \%$ of the market (France: $32.7 \%$; Italy: $24.8 \%$ and Spain: $21.9 \%$ ). The volume exportation of Brazilian sparkling wine has grown significantly in recent years $(4,210.2 \%)$, with Paraguay, China, Uruguay, the United States, France and the United Kingdom being the major buyers. The evolution of exports shows that Brazilian sparkling wine becomes an alternative to those produced in traditional countries, such as France, Italy and Spain, due to their quality and price. There is an increase in the commercialization of sparkling wines in the Brazilian domestic market, in addition to the growing participation of Brazil in the volume of exports in the world market, placing Brazil in a leading position in the production and sale of sparkling wines.
\end{abstract}

\section{Introduction}

The Brazilian viticulture occupies an area of approximately 83,700 hectares, with an annual production varying between 1,300 and 1,400 tons, in which about $40 \%$ of the production is destined for processing, and one of the featured products is sparkling wine [1]. According to Mello [2], Rio Grande do Sul and Santa Catarina States are the main producers, representing $95 \%$ of all fine wines and sparkling wines market in Brazil.

Vitiviniculture has been an important activity for the economy of some regions, especially those located in the south of the country, where the largest volume of grape, wine and other products is produced. The importance of the wine industry in South Brazil is entirely related to the sustainability of small and medium-sized rural properties, which produce table grapes and grapes for processing, as well as those that act in the winemaking system, in order to contribute to the generation of employment and income [3].

The production of sparkling wines is lower compared to that of fine wines, but the economic impact of this product is very important because of its high added value. For this reason customer awareness of the quality is increasing and winemakers are constantly looking for product improvements and newproducts. In recent years a

a e-mail: douglaswurz@hotmail.com newmarket strategy in the oenological industry, based on the diversification of wine production, has increased [4].

Brazil is a booming market for the consumption of wines and sparkling wines, although per capita consumption is still very low. While each Brazilian consumes on average about 50 liters of beer and 6 of cachaça a year, wine consumption (fine wines) is around 2 liters per capita per year [5]. The highest sales growth recorded by the Brazilian wineries are the sparkling wines, among them the sparkling Moscatel, according to the Brazilian Wine Institute [6].

Brazilian sparkling wines participation in the market has become stronger in the national scenario. With the commercial opening occurred in the early 1990 s, there was an entrance of imported wines from Chile and Argentina, subtracting space from the national products. However, this was not the reality of the segment of sparkling wines.

In the last 20 years, an increase in Brazilian sparkling wine consumption was recorded, as a consequence of the the increase in quality and tipicity, besides having a competitive price in the domestic market and in the foreign market.

Brazilian sparkling wines are the product of excellence for Brazilian winemaking, as recognized by awards in international enological contests and an increase in production and sales [7].

In this context, the objective of this work is to explore the evolution of the commercialization of Brazilian

(C) The Authors, published by EDP Sciences. This is an Open Access article distributed under the terms of the Creative Commons Attribution License 4.0 (http://creativecommons.org/licenses/by/4.0/). 


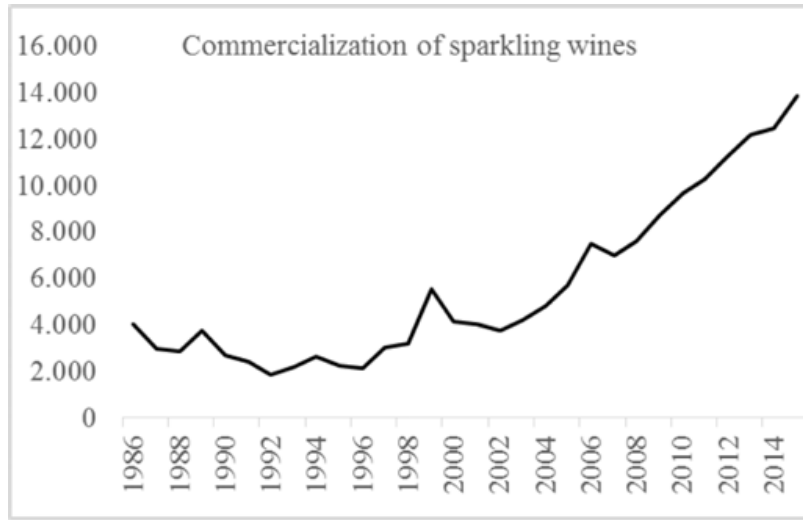

Figure 1. Evolution of the commercialization of sparkling wines in Brazil, in 1000 L, between 1986 and 2014.

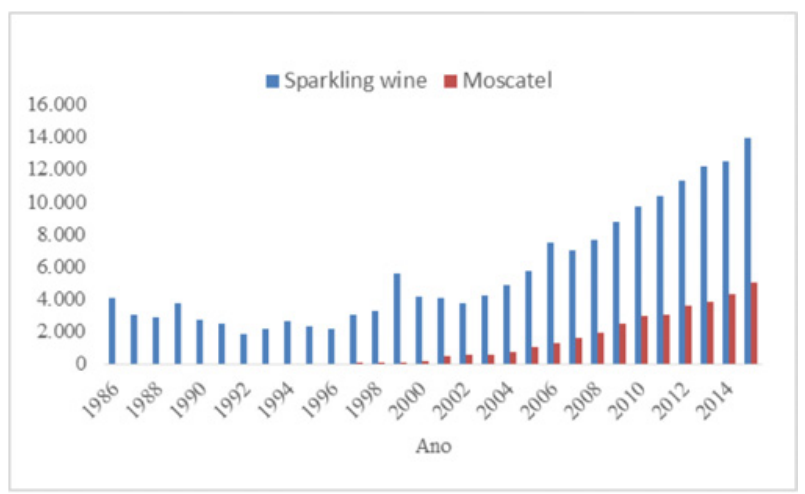

Figure 2. Commercialization volume (in $1000 \mathrm{~L}$ ) of sparkling wine (Nature, Brut, Demi-Sec) and Moscatel in Brazil from 1986 to 2014 .

sparkling wines in the internal and external market during the period 1990-2015, giving an overview of the current situation and its market trends, highlighting the importance of Brazil in the world scenario for sparkling wines.

\section{Materials and methods}

The study was based on a review of scientific literature and oficial data published by institutions responsible for collecting and disseminating data on the production and marketing of fine wines and sparkling wines in Brazil. For a characterization of the Brazilian sparkling wine market, the following data were researched from the last 30 years: commercialization of national products, importation and exportations.

The institutions assessed were: Instituto Brasileiro do Vinho, IBRAVIN , Embrapa Uva e Vinho, Ministério da Agricultura, Pecuária e Abastecimento, MAPA and União Brasileira de Vitivinicultura, UVIBRA.

All collected data were used to generate graphs with the purpose of showing the panorama and determining trends of the commercialization of wines and sparkling wines in Brazil.

\section{Results and discussion}

Brazil has a favorable scenario in the sparkling wines market due to the continued growth in the marketing of sparkling wines since 2000 (Fig. 1). From 1986-2015,

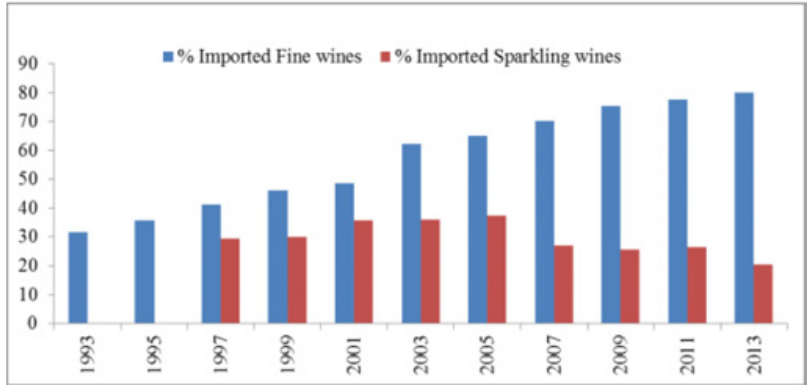

Figure 3. Percentage (\%) of imported fine wines and imported sparkling wines marketed in Brazil from 1993 to 2013.

there was an increase of $465.6 \%$ in the sales of sparkling wine in the Brazilian domestic market, especially the last ten, which accounted for an increase of $215.7 \%$.

This market is still characterized by seasonality and the consumption of sparkling wine is still lower than the other categories of wines, however, they have been growing sharply in recent years. Its consumption is mostly associated with special occasions and parties, such as the end of the year and other celebrations.

Before 2000, it was observed oscillations of the commercialized volumes of sparkling wines in Brazil. However, from the year 2006 onwards the growth in the marketing of sparkling wines became very significant, going from 7.5 million liters in 2006 to 12.9 million liters in 2014.

The growth of the sparkling wine is pronounced regardless of sparkling categories (Nature, Brut, Demi$\mathrm{Sec}$ or Moscatel). However, the Moscatel style is one of the most promissing categories. Between 2004 and 2014 , the volume of muscatel wine sales increased from 0.7 million to 4.3 million, representing a $614 \%$ increase in sales (Fig. 2).

One of the determining factors for the oscillations occurred in the commercialization of fine wines in Brazil is related to the quantity of imported wines marketed in the country. In 2014, imported fine wines accounted for $79 \%$ of the total volume of wines marketed in the country (Fig. 3). In 1993, imported wines accounted for only $19 \%$ of the fine wine market in Brazil.

According to Protas [8], the segment of fine wines faced a strong competition, registering significant growth rates of imported wines, due to the process of opening the Brazilian economy abroad. At the same time, Brazilian consumers started to drink more wines for the last 15-20 years, specially wines from Chile and Argentina [5].

Therefore, over the last 20 years, there has been a considerable increase in the share of imported fine wines marketed in the country (Fig. 4). While for the sparkling segment, there is an inverse trend, that is, over the years, imported sparkling wines have been losing space in the Brazilian market. Much is due to the quality of Brazilian sparkling wine, which over the years has been evolving in quality and conquering the national consumer.

When comparing the marketed values of imported sparkling wines and national sparkling wines, there is an inverse behavior of fine wines. For the sparkling segment, in 2014, only $20.5 \%$ of sells come from imported products (Fig. 4). In this context, there is a consolidation of sparkling wines in the Brazilian wine market. 


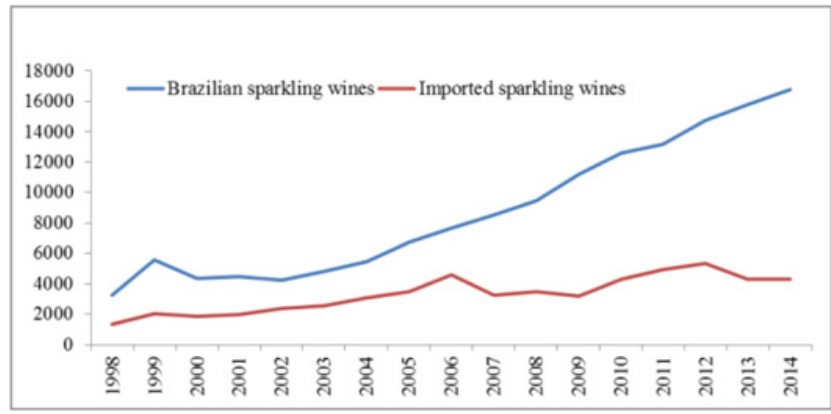

Figure 4. Total Commercialized Value (in 1000 liters) of imported sparkling wines and brazialian sparkling wines from 1998 to 2014.

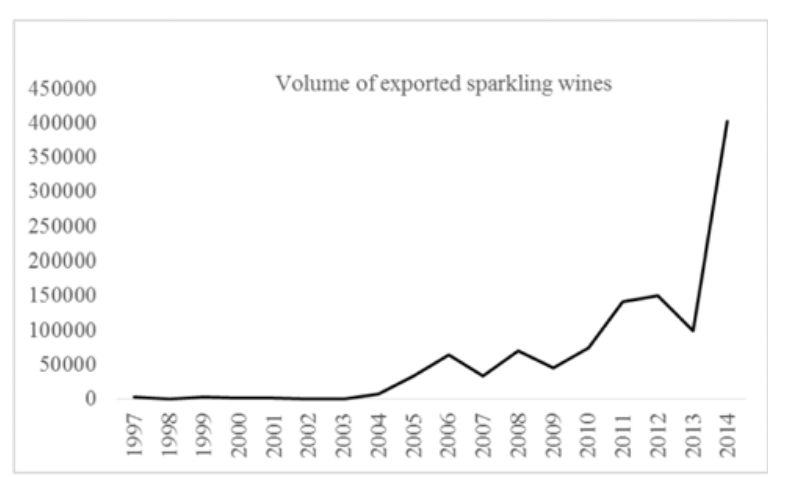

Figure 5. Volume of sparkling wines exported (Liters) by Brazil from 1997 to 2014.

Imported sparkling wines consumed in Brazil come mostly from six countries, which together account for $98.5 \%$ of the market: France represents $32.7 \%$, Italy $24.8 \%$ and Spain $21.9 \%$ [9].

The exported volume of Brazilian sparkling wine has shown a notable growth in recent years, with a growth of 4,210.2\% (Fig. 5), and the main buyers are Paraguay, China, Uruguay, the United States, France and the United Kingdom. The evolution of exports shows that Brazilian sparkling wine becomes an alternative to those made in traditional countries, such as France, Italy and Spain, due to their quality and price.

According to Caligari [10], Brazilian wine companies have a limited vision, focused on the present and usually to not predict what may happen in the near future, they have a simplistic way of managing, lack of technical and human resources, especially in the research and marketing. In this sense, the Brazilian Wine Institute - Ibravin, is developing the Wines of Brazil program.

The project Wines of Brazil aims to promote the expansion of the consumption of wines, sparkling wines and other grape derivatives in the Brazilian market. It develops promotional campaigns for consumers and channels, market access projects, fairs, tasting events and training of wine service teams. It is also responsible for the relationship of the sector with buyers, distribution channels, journalists, sommeliers and opinion makers. In the same sense, the Wines of Brasil team works in the dissemination of wine culture in the behavioral, gastronomic and technical fields, using an accessible language to all wine lovers. The program is funded by the Vitis Fund, besides the capital invested by the participating companies, and it is also supported by strategic partners such as SEBRAE and SENAC [11].

\section{Conclusion}

The evolution of exports shows that Brazilian sparkling wine becomes an alternative to those produced in traditional countries, such as France, Italy and Spain, due to their quality and price. There is an increase in the commercialization of sparkling wines in the Brazilian domestic market, in addition to the growing participation of Brazil in the volume of exports in the world market, placing Brazil in a leading position in the production and sale of sparkling wines.

\section{References}

[1] L.M.R. Mello. Vitivinicultura Brasileira: panorama 2013. (Comunicado Técnico 156, Embrapa Uva e Vinho, Bento Gonçalves, 6, 2014)

[2] L.M.R. Mello. Vitivinicultura Brasileira: panorama 2012. (Comunicado Técnico 137, Embrapa Uva e Vinho, Bento Gonçalves, 5, 2013)

[3] V.N. Duarte. Estudo da Cadeira Produtiva do Vinho em Santa Catarina: características e estágio atual. Evidências 13, 45-56 (2013)

[4] M.A. Pozo-Bayon, A. Martínez-Rodrígues, E. Pueyo, M.V. Moreno-Arrivas. Chemical and biochemical features involved in sparkling wine production: from a tradicional to an improved winemaking technology. Trend in Food Science Technology 20, 289-299 (2009)

[5] M. Copello. As regiões produtoras do Brasil. Revista Anuário Vinho do Brasil, São Paulo (2015)

[6] IBRAVIN - Instituto Brasileiro do Vinho Dados estatísticos - Produção de uvas no Brasil (IBRAVIN, Bento Gonçalves, 2015)

[7] M. Gabbardo, F. Battistutta, E.T. Gabbardo, L. Tat, E. Celotti. Aromatic characterization of Brazilian sparkling wines using olfactometry and sensory panel. BIO Web of Conferences 7, 1-5 (2016)

[8] J.F. Protas, U.A. Camargo, L.M. Mello. A vitivinicultura brasileira: realidade e perspectivas (Embrapa Uva e Vinho, Bento Gonçalves, 2002)

[9] OIV - Organization Internationale de la Vigne et du Vin. State of World Vitiviniculture situation (OIV, Paris, 2014)

[10] N.R.V. Caligari. Planificacin estrategica del sector vitivinicola de "Rio Grande do Sul" (Thesis, São Leopoldo, 291, 2000)

[11] IBRAVIN - Instituto Brasileiro do Vinho. Promoção e Comunicação Mercado interno - Vinhos do Brasil (IBRAVIN, Bento Gonçalves, 2017) 